\begin{tabular}{c} 
Volume and Issues Obtainable at Center for Sustainability Research and Consultancy \\
Sustainable Business and Society in Emerging Economies \\
ISSN:2708-2172 \&(E):2708-2504 \\
Volume 3: Issue 2, June 2021 \\
CSRE \\
Journal homepage: $\underline{\text { www.publishing.globalcsrc.org/sbsee }}$ \\
\hline
\end{tabular}

\title{
Impact of COVID-19 on Socio-Religious Integration in Developing Countries: A Case Study of India and Pakistan
}

*Nusrat Bano, Department of Political Science \& International Relations, Government College University Faisalabad, Pakistan

Ghulam Mustafa, Department of Political Science \& International Relations, Government College University Faisalabad, Pakistan

Anwar Ali, Department of Political Science \& International Relations, Government College University Faisalabad, Pakistan

*Corresponding author's email address: nusratb82@gmail.com

\begin{tabular}{l}
\hline ARTICLEDETAILS \\
\hline History \\
Revised format: May 2021 \\
Available Online: Jun 2021 \\
\hline Keywords \\
Social integration, Religious \\
integration, Corona virus, \\
Weak economy, Developing \\
Countries
\end{tabular}

\section{JEL Classification}

M1, M12

\section{OPEN ACCESS}

\section{ABSTRACT}

Purpose: Integrity is pre-requisite for the prosperity and development of the society. Stable integration is the sign of justice, equality, rights and duties which provides tolerated society and religious inclusion. But, developing countries still have many challenges to stabilize their socio-religious integration due to non-cooperative behavior among different segments of the society, lack of politico-religious tolerance and less socio-economic development. The other factors responsible are poor educational and health system, weak social institution, marginalized segments of society, absences of culture of welfare state. Likewise, in India, communal conflicts remain present in every time as well as Pakistan faces sectarian tension and in both countries, religious norms and attitudes are used for political purposes. Similarly, both countries have the challenges of inequality and injustices within their communities.

Design/Methodology/Approach: The qualitative techniques have been applied in this research. Date has been collected from Secondary and Primary Sources.

Findings: Economic development is necessary for the development of the social prosperity without it socio-religious integration is a dream.

Implications/Originality/Value: The epidemic COVID-19 has challenged the socio-religiosity of the developing countries which affected the socio-economic and religious set up of these countries ruthlessly.

(C2021 The authors, under a Creative Commons Attribution- Non Commercial- 4.0

Recommended citation: Bano, N., Mustafa, G. and Ali, A. (2021). Impact of COVID-19 on SocioReligious Integration in Developing Countries: A Case Study of India and Pakistan. Sustainable Business and Society in Emerging Economies, 3 (2), 125-131. 


\section{Introduction}

Socio-religious integration is pre-requisite for the development of the country. It detail may be subjective in socio-religious harmony and political hypothesis. Social integration is refers to promotion of values, institutions and relations which enables society to participate all sphere of life on the basis of rights, equalities and justices. Society is called the relationships of individuals which are united systematically for common and collective objectives. It is organized by modes of behavior, institutions and associations which individuals are bound for collectivity. While, culture refers as part of to society having common characteristics, cluster of social norms, attitudes and institutions.

Traditionally, religious beliefs, ideas and values have major contribution for the development of the societies and its cultures. Religiosity provides guideline to human relating to human identity, nature, purposes and role of religion in his life. It directed the individuals understanding the value of the world and actions of community. More, it suggested that how religious values influence societal norms and attitudes. Thus, religion develops cooperative behavior within society and promotes the culture of socioreligious harmony.

Historically, religion could be traced from all humanities including ancient human societies symbolizing their beliefs and practices. Religion is a cluster of cultural systems, belief systems and universal acceptance that develop the mindset of worships through ritual practice. It plays the central part in all human activities guiding people and shaping human in which they live. According to sociological approach, religion prevails around the world both in belief system and social institutions preaching individual specifically under religious premises, promoting collective consciousness and sense of belonging. While, as a part of social system, religious in most of societies had influential role both in economic and political segments (Oluwaseun, David, \& Issa, 2013).

The outbreak of virus is termed COVID-19 by SARS-CoV-2 virus. It has originated from the Wuhan, city of China located in Hubei province in December 2019. It has travelled other countries and now, it was identified in Italy, South Korea, Iran, and Japan. Although, China because of its well structured socio-economic set up and stronger medical sector tried to curb it effectively, but other countries where and when it emerged posed greater uncertainly and unrest including all developed, developing and under-develop region of the world. World Health Organization (WHO) declared health emergency to fight against epidemic. It became more painful when precautionary measures were taken to combat it, including social distancing, and banned travel movements, events, education and entertainment industries (Ozili \& Arun, 2020).

The main purpose of the research is to investigate the socio-religious integration in developing countries and impact of COVID-19 on it. It describes the social, religious, political and economic relations in the developing countries. It examines that how COVID-19 challenged the religiosity in developing countries specifying India and Pakistan. It describes the impact of COVID-19 on the communities of the developing countries.

\section{Socio-Religious Integration}

Cooperation among different segments of society is guaranteed to social solidarity and integration in a nation state. Basically, social integration is the sign of cultural acceptance, inclusive politics, and promotion of social institutions. Social integration governs the behavior of the members of the society; promote equality and social justice within society. It is considered the process of socio-political participation equally within diversity without any discrimination including caste, ethnicity, religion, sect and political ideas. It neglects the social exclusion giving rights and opportunities which negates sense of self deprivation and extremism. In contrary, lack of integral social set up increase the threat of war and conflicts in the society (Cruz-Saco, 2008).

Social integrity is associated with identity, values and rights without it there is not concept of social 
integration which could be caused of lose of ambitions, confidence and self-esteem. Moreover, social injustices and institutional inequalities prevails poor social behavior which gives the birth of marginalized and prejudice society. In many societies, domestic violence and gender discrimination is common due to disparities and absence of socio-economic equality. Politically, collective decision making and political participation assures harmony and prosperity in a society but without it there is no political rights, rule of law and good governance which could be caused of disintegration and dispersion of both society and state. Moreover, marginalization on the basis of religion, ethnicity and culture disturb the whole setup of the society as well as country.

Interestingly, religious can be found in every society and accepted as an institution of the society. In the map of glob very few societies existed without religion even it prevails in secular western countries where more than one third population believe in God. It is the significant element and inevitable part of politics and social life. It influences the political ideology and policy making behavior of the country. Religious identity is interlinked to political activities including rule of law, democracy, voting behavior, lobbying and participation. It is considered source of legitimacy justifying aims and objectives as well as policies and action or acceptant and rejection of government in most of the countries. So, on that result, religiosity supports, engage and regulate the governments and its policies. Government could not denied and restrict the importance of religion in politics (Fox, 2012).

\section{Challenged of Socio-Religious Integration in Developing Countries}

In developing states, the aim of stable social structure could not be established properly due to several challenges. Firstly, in most of developing countries, poverty is one of major reason which hurdles to social prosperity and development in developing countries. Secondly, social injustices develop the marginalized segments of society which people are deprived to their rights, opportunities and could be reasoned of social disintegration. Thirdly, due to less economic opportunities in developing countries spread uncertainly, unrest and poverty, backwardness, less socio-economic development in these countries. Fourthly, poor health, weal living standard and poor educational institutions are the cause malnutrition, diseases and illiteracy in developing countries including India and Pakistan.

Social integrity can be examined by levels of education, health, economy, equality, justices, modernization, communication and status of women. For example, in India, socio-religious integrity is not uniformed due to wide range of religious and regional disparities. Majority of people have no access to good quality of food, safe drinking water, good quality education and health care infrastructure. For example, despite of secularist recognized ideology of India, its nationalists promote Hinduism in India neglecting minorities including Muslims and Christians, due to that reasons countless Muslims, lowcaste Hindus and Christians have been killed, tortured. India due to its inequalities is going to social disintegration instead of unity and multiculturalism. For example, several types of movements were started against religious extremism by suppressed communities (Mahadeva, 2016).

In Pakistan, culture of development has a very low success rate due to absence of clarity about to aims and objective, inconsistencies, budget constraint and absence of experts who could deal skillfully with regional issues. Moreover, feudal mindset is still considered responsible to backwardness and poor social development especially educational and economic development. According to International Monetary Fund (IMF) despite of some efforts, Pakistan still have low progress in gender equality, most of people have poor economic status and women have less socio-economic benefits only $25 \%$ women participation in economic sector as compared men have $83 \%$ as well as Pakistan has very low literacy rate $35 \%$ young women are illiterate (Sydorenko, 2019).

Historically, sectarianism is the major issue of Pakistan challenging political, social, economic and cultural and even security order of the country. It had destabilized the law and order of the county as well as causing social disorder, unrest and violence in the society. More interestingly, it gave birth to terrorism, radicalism and religious extremism in the Pakistan. It not only divided the Muslims of 
Pakistan but whole Islamic world, it is considered the root cause of all evil (Mahsood, 2017).

India is the multi-religious country having communal conflicts between Hindus and Muslims. Historically, partition plan was decided India-Pakistan, due ghastly communal or religious violence between two communities Hind-Muslim. Unfortunately, the geographical division was not solved the communal tension and Muslims were blamed for the partition of the sub-continent. Basically, the conflict between two communities has the nature of more socio-political interest and less religious (Eckert, 2009).

\section{Socio-Religious Integration in Developing Countries and Impact of COVID-19}

As one commentator put it, "the coronavirus has turned the global market into the global hospital". It impacted every single individual beyond the country and paralyzed the world social, economic, religious and political setup. Even the most developed countries of the world seem vulnerable to deal with virus. Now, COVID-19 became epicenter of developed states and disturbing new world order. So, what about the developing and poor countries? South Asia consisting of $1 / 4$ population of the world is considered most threatened region and impact of COVID-19 could be much more devastating giving poor health and economic infrastructure.

Both India and Pakistan as well other developing countries, most of the people living below poverty line, the consequences of the COVID-19 would be more serious which would be result of socio-political decline and increasing risk of violence. Pakistan is already struggling to keep save livelihoods and maintain its health sector within its weakest economy. So, the explosion of the COVID-19 challenged the capability of the health sector and economic well-being of state of Pakistan. Unfortunately, state of Pakistan already survived under fragile economy both internally and externally. The fiscal deficit is on the decline having more than 41 trillion which almost $94 \%$ of the GDP of the country. So, in that situation, Pakistan has to divert its limited resources to fight against pandemic (Hussain, 2020).

United Nation warned that billions of people of developing states are on the edge of economic devastation due to pandemic and overburden of COVID-19. Likewise, India is consisted of most of backward regions having extreme poverty, mal nutrition, crippled health institutions, poor sanitation access, due to lockdown these backward and poorest regions faced with extreme poverty and deprivation which would be resulted of more hunger and starvation. The families from rural areas are being faced with little saving, poor social security net, borrowing money, having with fewer meals and facing the threat of police violence. The World Health Organization said, it seems lockdown could overcome the threat of COVID-19 but it enhances dangerous consequences for the poorest and most vulnerable people of the country. Others, many developing states including tourism driven nations and oil-exporting nations are being pushed toward debt crisis. If these debts were not overcome, it would lead for the long term which could be caused of poverty and unemployment (Suleymanova, 2020).

According to United Nations Development Programme (UNDP) affected developing countries will take year to recover their economies. The loss of employment and income affected sever outcome regarding areas such as food security, education and human rights. The institution warned health centers of developing countries have to run under poor recourses which increases the threat of spread of virus. The UNDP further argued that more than $75 \%$ of people in under develop region have no access on water and soap which resulted of highly transmission of COVID-19 among the poorest communities (Suleymanova, 2020).

Likewise, other countries, Pakistan have also shut its cities, borders as well as all sorts of activities across the country. The decline of international economy also affected the economy of Pakistan due to decline of tourism, falling oil prices and global airline industry and decline transportation. For instant, oil prices have been declined below $\$ 30$ per barrel internationally due to price conflict between Russia and Saudi Arabia and on the eve of it, stock market of Middle has plunged East (Rehman, 2020). 
Likewise, India, Bangladesh and Nepal Pakistan have the challenge of malnutrition among children, food insecurity which poses the threat of COVID-19. The Vice President World Bank, Hartwig Schafer warned the South Asian Region regarding prolonged national lockdown which would be caused of negative economic growth rate. Likewise, both main exporters Pakistan and Bangladesh of the South Asia would suffer with serious consequences, because COVID-19 epicenter's countries were the buyers of their items, food, textile, tobacco and garments. On that result, poor people would be suffered with unemployment and rural poverty would be increased. He argued that the economy of the half of the South Asian countries would experience its worst performance in 40 years. The harsh reality was that poor would become poorer and more affected with virus due to lack of facilities to maintain social distancing. Further, government seems vulnerable to maintain lockdown for a long time as well as to provide basic necessities of life for their citizens. The World Bank emphasis main priority of the governments to combat COVID-19 and to secure their poor native especially they are under the threat of poor economic and health facilities(Rana S., 2020).

Unfortunately, in developing countries, security of the individuals is defined on the basis of gender, race, age, ethnicity and geographical location. On that result, people belonging to vulnerabilities, like children, women, migrants, poor people and people of backward areas suffer a lot with human led disasters and natural calamities. During implementation of lockdown and social distancing, these factors faced greater risk. It is mandatory for government to regulate these vulnerable factors regularly and properly. The havoc of COVID-19 increased the psychological, economic pressure and threat of domestic abuses in a society (Hasan, 2020).

UN report warned, spreading COVID-19 in emerging economy like, both India and Pakistan would be harmful due to significant decrease in export, declining foreign exchange and increasing unemployment. The decline of oil prices would further complicate the situation resulting losses of jobs for Indian and Pakistani migrant labor in Gulf States. It could be caused of widespread social unrest and economic chaos for emerging economies of the world (Afzal, 2020).

Pakistan is religious recognized state in the map of the world practicing religious rights freely and independently. Recently, the state of Pakistan has affected by coronavirus due to its religious gathering inside and outside the country. Initially, majority of corona affected people returned from neighboring state Iran and other inside the country. Suddenly, Coronavirus disease (COVID-19) surrounded the whole world including Pakistan. According to estimation, the havoc of COVID-19 surrounded the whole country within two weeks. However, the disturbing element is that, it increased involving people that did not have travel history. Pakistan has not well potential in resources and equipment to curb the virus as compared to developed countries. Further, the population of Pakistan more than Iran and Italy and $16^{\text {th }}$ most populated county of the globe. The cities of the country, Karachi, Lahore are populated cities having more than 10 million people separately (Jamal, 2020).

Basically, power is largely associated with wining confidence and trust of the people who give mandate for the protection of their interests. More, the supreme law of the country comprehensively defines the relations between people and state. For example, religious actors and government have two sources which protect people in time of crisis. The government could provide sense of security through its action and policies and religious actors through their belief.

Medically, all sorts of gathering could be caused of spreading the coronavirus disease. Whether, it is linked with travel, mass migration and religious prayers. In Pakistan, both experts and officials agreed that proper lockdown could not be successful without neglecting religious gatherings. The preachers of Tableeghi Jamaat (TJ), Shia pilgrims of Pakistan and continuation of Friday congregations were considered responsible spreading havoc of COVID-19 in Pakistan. In Pakistan, hundreds of cases were associated with TJ gathering in Raiwind and pilgrims of Iran. Moreover, COVID-19 complicated the relations between government and religious actors, Last week, clergy of the religious ideological groups 
refused to demands of the government to maintain social distancing (Jamal, 2020).

Similarly, other Muslim and Non-Muslim countries also are facing same challenges which further complicate the situation. For example, TJ gathering in India, Pakistan and Malaysia contributed to spread virus more quickly. According to dawn estimation more than half of Malaysia's Covid-19 affected people have been directly linked to the activities of TJ which were held in Kuala Lumpur by the end of February as well as other countries including Thailand, Philippines, Indonesia and Tunisia and Kuwait (Jamal, 2020).

Unfortunately, both in India and Pakistan, the pandemic has increased the sectarian and communal tension. The Muslim community was being responsible spreading virus in a country by the Hindu nationalist groups. Unlike, Pakistan was also divided by sectarianism, Shia pilgrims returning from neighboring country were not treated properly both by centre and provinces due to some causes including transmission of virus to local as same threat posed by the TJ gathering. Initially, sectarian hatred remained present at social media and later, sectarian hatred reactivated as groups who were banned by the authority (Rana M. A., 2020).

New Delhi claimed that 8,000 people visited religious gathering including locals and foreigners in the early March which were caused biggest coronavirus spike in India. In one hand leadership of Jamaat was blamed of "Carelessness" on other hand government was criticized for delaying response to act against foreigners who coming from COVID-19 epicenter's countries including Indonesia, Malaysia and even within India. The Tabligi Jamaat was blamed and charged ignoring rule and regulations about social distancing enforced by the government to overcome pandemic. On that result, authority registered number of case against Tabligi leadership under the Epidemic Disease Act as well as authority has blacklisted the 960 foreigners for violating visa norms. The Jamaat pointed that the gathering was suspended immediately after government requested them. The Jamaat also blamed screening process was not conducted properly and number of people carried the virus who back to their homes (Bisht \& Naqvi, 2020).

Not only The jammat but also 200 million Muslim of the country were blamed spreading COVID-19 in India through mainstream media, leaders of ruling Bharatiya Janata Party termed Corona Jihad, Talibani crime and Corona terrorism. Faizan Mustafa, a constitutional expert, argued to Al Jazeera news that it is unfair using term Corona Jihad and media should play positive role ignoring mischievous behavior and government should adopt greater rationality rather than prejudice nature. (Bisht \& Naqvi, 2020).

In other countries both socio-religious matters are taken with the executive order in situation of emergency but in Pakistan, government seemed vulnerable towards religious agents regarding suspension of religious gathering. This lenient behavior show government incapability to deal religious affairs and could be caused of increasing more sectarianism and radicalism. Although, to curb COVID19 has little room for the populist tendencies but the government has to change its sources of inspiration and learn from other countries including China, New Zealand, South Korea, Germany and Japan.

\section{Conclusion}

It is concluded that developing countries have multi-dimensional challenges within their hometown. The aim to socio-religious integration is still a myth in the developing counties. Traditionally, the societies of these countries have conservative characteristic due to less modernity and advancement in technology resulting less socio-religious integration priorities of these societies. Thus, true development can be possible with the improvement of educational and health, economic sector and promotion of social justices and equality in the country. Both institutions and government should overcome their weakness in dealing with religious affairs and actors. Government should take decision encouraging religious scholars rather than religious individuals, parties and brands and no one should be allowed to use religion for political purposes. Moreover, interestingly, the impact of COVID-19 different to each 
country due to different causes and effects. India having large portion of poor population, limited state capacity and limited heath care resources resulting collapse of health sector and social unrest. The policy of shutdown affected the poor segment of society ruthlessly. According to Chinese experts, it is necessary to maintain social distancing, harsher lockdown, and increasing more and more testing capacity to combat COVID-19. But the governments of developing nation are not financially capable to take decision effectively. Now, it will not possible without the support of international organizations and international communities. Other, religious agents and common people have to cooperate with government being responsible citizens of the country.

\section{Reference}

Afzal, A. (2020, 4 16). Pandemic Economics. Retrieved From Dawn.Com: Https://Www.Dawn.Com/News/1549633/Pandemic-Economics

Bisht, A., \& Naqvi, S. (2020, 4 7). How Tablighi Jamaat Event Became India's Worst Coronavirus Vector. Retrieved From Aljazeera.Com: Https://Www.Aljazeera.Com/News/

Cruz-Saco, M. A. (2008). Promoting Social Integration: Economic, Social And Political Dimensions With A Focus On Latin America. Journal Of Philosophical Economics, 1-10.

Das, A. (2004). Socio-Economic Development in India: A Regional Analysis. International Journal of Management Research 313-345.

Eckert, J. (2009). The Social Dynamics Of. International Journal Of Conflict And Violence • , 173-190.

Fox, J. (2012). Religion, Politics, Society, And The State. Oxford University Press, 1-10.

Fox, J. (2012). Religion, Politics, Society, And The State. Oxford University Press, 1-10.

Hasan, S. (2020, 4 6). Steps Sought to Stop Possible Rise in Domestic Violence During Lockdown. Retrieved From Dawn.Com: Https://Www.Dawn.Com/News/1546756/Steps-Sought-To-StopPossible-Rise-In-Domestic-Violence-During-Lockdown

Hussain, Z. (2020, 4 15). Pandemic's Economic Impact. Retrieved From Dawn.Com: Https://Www.Dawn.Com/News/1549307/Pandemics-Economic-Impact

Jamal, U. (2020, 3 24). First: How Islamists Are Undermining Pakistan's Fight Against Covid-19. Retrieved From Thediplomat.Compilgrims: Https://Thediplomat.Com/2020/03/Pilgrims-FirstHow-Islamists-Are-Undermining-Pakistans-Fight-Against-Covid-19/

Mahadeva, D. (2016, 8 15). Dreaming Again For Equality In India. Retrieved From Aljazeera.Com: Https:/Www.Aljazeera.Com/Indepth/Opinion/2016/08/Dreaming-Equality-India160815085235657.Html

Mahsood, A. K. (2017). History Of Sectarianism In Pakistan: Implications For Lasting Peace. Journal of Political Sciences \& Public, 1-10.

Oluwaseun, A., David, F. O., \& Issa, A. A. (2013). The Role of Religion in Modern Society: Masses Opium Or Tool For Development: A Case Study of Saw-Mill Area, Ilorin, Kwara State, Nigeria. International Journal Of Sociology And Anthropology, 1-15.

Ozili, P. K., \& Arun, T. (2020). Spillover Of Covid-19: Impact on the Global Economy. Ssrn Electronic Journal, 1-10.

Rana, M. A. (2020, 4 5). Covid-19 and other Fears. Retrieved from Dawn.Com: Https://Www.Dawn.Com/News/1546527

Rana, S. (2020, 4 12). Pakistan May Fall into a Recession due to Covid-19: World Bank. Retrieved From Tribune.Com: Https://Tribune.Com.Pk/Story/2196221/2-Pakistan-May-Fall-RecessionDue-Covid-19-World-Bank/

Rehman, D. F. (2020, 3 23). Spread of Covid-19 And Pakistan's Economy. Retrieved From Tribune.Com: Https://Tribune.Com.Pk/Story/2181841/2-Spread-Covid-19-Pakistans-Economy/

Suleymanova, R. (2020, 4 9). Coronavirus: Un Unveils Plan to Rescue Countries Facing Collapse. Retrieved From Aljazeera.Com: Https://Www.Aljazeera.Com/Ajimpact/Coronavirus-UnveilsPlan-Rescue-Countries-Facing-Collapse-200409131018506.Html

Sydorenko, T. (2019). Request for An Extended Arrangement under The Extended Fund Facility-Press Release; And Statement by The Executive Director for Pakistan. Washington, D.C.: 2019 International Monetary Fund. 